\title{
Recomposing the Nation
}

Conceptions and effects of heritage

preservation in religious universes ${ }^{1}$

\section{Emerson Giumbelli}

\begin{abstract}
This article seeks to contribute to the field of studies that, inspired in debates about ethnicity, discusses the forms and components of the notion of nationality. How and with what elements is "Brazilian culture" constituted? This question guides the study of landmark designation processes conducted by the National Artistic and Historical Heritage Institute, a federal agency operating since 1937. Considering landmark designation as a form of official recognition of a site as "cultural heritage", the article reflects on the impact of this policy on two religious universes: Catholicism and Afro-Brazilian religions. The conclusions point to distinct forms of recognition of religious universes and to transformations in ways of conceiving nationality.
\end{abstract}

Keywords: Catholicism, Afrobrazilian religions, Brazilian culture, cultural heritage

\section{Resumo}

O texto procura contribuir para a linha de estudos que, inspirada em debates sobre etnicidade, problematiza as formas e os componentes da noção de nacionalidade. De que maneira e com que elementos se constitui a "cultura brasileira"? Tal indagação orienta a pesquisa de processos de tombamento conduzidos pelo Instituto de Patrimônio Histórico e Artístico Nacional,órgão federal que existe desde 1937. Tomando o tombamento como uma forma de reconhecimento oficial de um objeto como "patrimônio cultural", procura-se refletir sobre a incidência dessa política sobre dois universos religiosos: o catolicismo e as religiões afrobrasileiras. As conclusões da pesquisa apontam

1 This text presents research results related to the project "Religion and public space in three fields" (Religião e espaço público em três âmbitos), which is supported by a grant from CNPq (The National Council for Scientific and Technological Development). 
para formas distintas de reconhecimento do religioso e para mutações nos modos de conceber a nacionalidade.

Palavras chave: catolicismo, religiões afrobrasileiras, cultura brasileira, patrimônio cultural 


\section{Recomposing the Nation}

Conceptions and effects of heritage

preservation in religious universes ${ }^{2}$

\section{Emerson Giumbelli}

On 31 May 1984, a meeting of the Advisory Board of the National Artistic and Historical Heritage Institute (IPHAN) was held. IPHAN is the federal agency responsible for "heritage" protection policies and measures (Gonçalves 1996, 2007; Choay 2001; Chuva 2009). The Advisory Board is its decision-making body, which acts on the basis of advice from IPHAN's own technicians and at times outside consultants. Exceptionally, the meeting took place in Salvador, in the great hall of the Santa Casa de Misericórdia, a Catholic institution devoted to healthcare services. At the beginning of the meeting, the Primate Cardinal entered the hall only to praise the "action of [I]PHAN in the preservation of the country's monuments of art, culture and faith" and to thank the institution for providing the resources necessary for the conclusion of the restoration of the Basilica Cathedral of Salvador. ${ }^{3}$ Having been greeted by everyone present, the Cardinal left the room, without participating in the main discussion on the agenda. The Board was evaluating a proposal for protection for the Casa Grande, or the Ilê Axé Iyá Nassô Oká, a Candomblé terreiro with the prestige of being "one of the oldest and most traditional" in Salvador and Brazil. In a tense meeting, the proposal was approved. For the first time, a temple of an Afro-Brazilian religion gained landmark status, some 46 years after the Cathedral mentioned by the Cardinal had been similarly designated, which is included in the list of the first buildings granted landmark status by IPHAN.

This event - which will be the object of other observations below - seemed emblematic to me for the purposes of this article. The simultaneous presence and distinct positions of Catholicism and Afro-Brazilian religions constitute a privileged situation for the questions I would like to raise in relation to

\footnotetext{
2 This text presents research results related to the project "Religion and public space in three fields" (Religião e espaço público em três âmbitos), which is supported by a grant from $\mathrm{CNPq}$ (The National Council for Scientific and Technological Development).

3 The account mentions the minutes of the meeting, which form part of File 1067-T-82, Archive of IPHAN.
} 
the landmark designation processes undertaken by IPHAN, a federal body in continuous operation since its creation in $1937 .{ }^{4}$ My questions involve the relationship between cultural policies and religious universes, which force us to consider transformations over time of the distinct ways in which religion is recognized by the state. The framework within which these questions are posed - and which they contribute to modify - is composed of the historical and social ways in which "national culture" is conceived in Brazil.

I do not intend to present general or theoretical considerations about the notion of ethnicity. I begin with the understanding that the conception and imagination of nationality, linked to specific practices and institutions, may be studied recognizing the notion of ethnicity as a reference. This involves considering the elements that constitute nationality according to certain visions, discourses and procedures. What constitutes the Brazilian nation? This question raises the issue of the link between ethnicity and nation. ${ }^{5}$ In this article, this question leads to the field of religious diversity and the asymmetries it contains. I analyze the universes of Catholicism and AfroBrazilian religions, in their relation to heritage protection policies. I thus pose my key question: What are the ways in which Catholicism and AfroBrazilian religions are recognized as a synonym or part of national culture?

There is no doubt that this question has already been posed from other points of view. Many authors have demonstrated the close relationships between Roman Catholicism and Brazilianness (brasilidade), ${ }^{6}$ because of its fundamental importance to the entire colonization process; as the religion of the majority of the contemporary Brazilian population, as shown by statistical surveys about religious affiliations; and as a basis on which social relationships are established. In the case of Afro-Brazilian religions, we have a different picture, to the extent that their participation in national culture takes place through other channels: artistic expressions in various genres, specific

4 The name of the agency has changed during its history. It was created as the National Service of Historical and Artistic Heritage. IPHAN is the acronym of its current name, which I use in the text. Landmark designation (tombamento) refers to the classification of an object, building or place as part of the "national heritage". Owners of these designated objects, buildings and places are responsible for their preservation, with some public resources at their disposal to that end. For more details, visit http://portal.iphan.gov.br/portal/montarPaginaSecao.do?id=1 $7738 \&$ sigla=Institucional\&retorno=paginaInstitucional (Access on $07 / 10 / 2014$ )

5 As inspiration for this type of problematization, I can point to a set of broad and collective discussions, among which I highlight: Fry (2005), Maio and Santos (1996), Schwarcz (1993, 1999), Sansone and Pinho (2008). For other contexts, see: Handler (1988), Van der Veer (1994) and Comaroff and Comaroff (2009).

6 Some examples can be mentioned: Sanchis (1994), Novaes (2002), Brandão (1988), Fernandes (1994), Montero (2012). 
cuisines, and, mainly, their association with Negritude or Africanness that are also understood as constituents of the nation, including in historical terms. These forms of participation in a national culture coexist with the minority status of these religions. ${ }^{7}$ Meanwhile, the recent rise of Evangelical churches threatens both Catholicism and Afro-Brazilian religions, but more the latter than the former. There is as yet no consensus on the position of the Evangelical religions vis-à-vis Brazilian nationality or culture. ${ }^{8}$

The object of this text, has as reference a more specific, but also privileged, field. IPHAN, is one of the main places where conceptions are articulated about "national culture" and practices that have an effect on different social spheres, including the religious ones. I will first consider the relationship between cultural protection policies and Catholicism. This exploration is not based on specific cases, but on data and analyses - developed by other researchers - that demonstrate how the link between Catholicism and national heritage is conceived. I pay special attention to the formative first decade of IPHAN's activity. But I also go back to the previous years that established the context in which the protection policies were conceived. I then focus on the Afro-Brazilian universe, analyzing seven landmark designation processes of terreiros carried out by IPHAN, since the 1980s, highlighting the arguments that justify the consideration of these new heritage sites. Finally, I analyze the landmark designation process in 2006 of the Christ the Redeemer monument in Rio de Janeiro. In this way, by returning to Catholicism I explain how the relationship between nation and religion has been reconfigured in recent times.

\section{Cathlic Churches}

It is difficult to ignore the importance of the Catholic religion on Brazil's official heritage policy. From the creation of IPHAN, in 1937, until 1946, over 50\% of the landmarks registered were Catholic churches (Chuva 2009: 128). The Catholic Church was also the main beneficiary of restoration works, almost always financed by public resources, according to Chuva. The period in question - 1937 to 1946 , which accounts for over $40 \%$ of all landmark designations

\footnotetext{
7 For analyses about the position of Afro-Brazilian religions see: Birman (1997) and Silva (2006).

8 While the classic analysis made by Sanchis (1994) emphasizes a counter position, recent works like that carried out by Cunha (2008) suggest proximities.
} 
in Brazil until 1997 - was one of the most active in the history of IPHAN, for a reason that is easy to understand: the intention was to realize, through administrative decisions, the project that gave birth to the body itself, which was simultaneously committed to the preservation of buildings and the construction of a national memory.

The city of Ouro Preto was paradigmatic at the moment of the creation of Brazil's heritage policy. Even before the creation of IPHAN, a governmental order of 1933 declared the city a "National Monument", along with other historical cities in Minas Gerais state, where entire districts with distinctive architecture were designated as landmarks, Catholic temples stand out among the objects for which protection measures were approved. They also benefited from restorations during the following years. Ouro Preto had two attributes. On one hand, it was appreciated by those who admired its past and legacies for the present, and it served as a sort of $18^{\text {th }}$ century reliquary. On the other hand, it attracted the fascination of the modernists, who in the 1920 s chose it as a favorite destination for their cultural trips; they also perceived convergences between the past and the modern, constituted by the construction of a hotel designed by Oscar Niemeyer. For these reasons, the city received special attention and acted as a modern model of an historical city (Chuva 2009). 9

According to Chuva (2009), turning the Colonial style of $18^{\text {th }}$ century Minas Gerais into an architectural model contributed significantly to the origins of the federal heritage protection policy. But Bahia and Pernambuco also had important locations, , and not only those considered precursors of the Baroque style that was consolidated in Minas Gerais. In any case, this Baroque was established as a paradigm and model, mainly incarnated in Catholic churches. The churches were considered from two perspectives, according to Chuva. Firstly, as incarnations of the ideals of the "fine arts", which identified that which was most valued by IPHAN; secondly, as historical reminiscences, with antiquity as the determinant criterion. The importance of the three aforementioned states and also of the former national capital (Rio de Janeiro) is clearly shown in the statistics: "Seventy-five per cent of the landmark designations of the period took place in the states of Bahia (28\%), Rio de Janeiro (22\%), and Minas Gerais (15\%), whose historical cities are

9 For another historical city in Minas Gerais, see Camurça and Giovannini (2003). 
counted individually in this percentage, but in fact there were hundreds of buildings designated in all, and Pernambuco (10\%)" (Chuva 2009: 189).

The concentration of actions in these three states cannot be considered separately from initiatives and structures that were engaged in similar questions even before the creation of IPHAN. State Agencies for the Inspection of National Monuments were created in Bahia and Pernambuco in 1927 and 1928 respectively. In Pernambuco, according to Medeiros (2005), the agency's photographic archive and inventory of buildings, furniture and other objects, was already dominated by "the presence of religious architecture, considering that the history of Pernambuco combines to a great extent with the history of the Catholic Church" (:6). In Minas Gerais, there existed a committee whose report was presented in 1925, together with a proposed law. Other laws came at the federal level, which not by accident were presented by congressional representatives from Bahia and Pernambuco. The leading role of these three states was accompanied by another characteristic: the action of people linked to Catholicism. Luiz Cedro Carneiro Leão, a Catholic intellectual, was a congressman from Pernambuco who presented the pioneering proposal for national heritage legislation in 1923. Another Catholic intellectual, Gustavo Barroso, director of the National Historical Museum in Rio de Janeiro founded in 1922, was involved in the initiatives in Bahia and Minas Gerais. One of the members of the Minas Gerais congressional delegation was, in turn, D. Helvécio, Bishop of Mariana (Chuva 2009; Iphan 1980).

The importance of these Catholics in the government apparatus in charge of heritage protection should not be exaggerated. In the case of IPHAN, at least, it was conducted by people with no links with the Catholic Church. Moreover, as Chuva (2009) shows, there were several situations of tension with ecclesiastical authorities, when they opposed the proposals for designating certain temples as landmarks. On the other hand, a bill presented by Congressman Araújo Pinho, in 1930, proposed the presence of a representative of the clergy on the council responsible for landmark designations (IPHAN 1980). And in the internal regulations of the federal apparatus in force in 1961, the expression "ecclesiastical authority" appeared, indicating it was an instance recognized by IPHAN. "Very close relationships, but not always harmonious" ones (Chuva 2009: 181), therefore, marked the proximity between the state and the Catholic Church. Why was this possible?

To answer this question, we can turn to the historian Ribeiro (2009) who 
sought to identify the factors that allowed a certain Catholic vision regarding the national formation gain legitimacy among Brazilian intellectuals in the early $20^{\text {th }}$ century - that is, exactly in the period in which heritage protection projects were forged. This is partially related to the positions achieved by Catholic intellectuals in historical institutes and arts and science academies. The best example may be Affonso Celso, who was president of the Brazilian Geographical and Historical Institute (IHGB) and author of educational books. While as an official he affirmed the benevolence of Portuguese colonialism, as a writer he praised the role of Jesuits in Brazilian history (Ribeiro 2009: 210ff).

A certain convergence of interests is observed in two records presented by Ribeiro (2009: 214): ecclesiastics used the inaugural address at IHGB to attack the separation between the Church and the State; inversely, lay members from the IHGB recognized the role of the Catholic religion in the historical formation of the nation. Inside the Catholic universe, this historic vision had been developed from at least the early $20^{\text {th }}$ century, achieving in the 1920 its most consolidated formulations, in the interventions of important intellectuals, such as Jackson Figueiredo and Alceu Amoroso Lima. A key idea of that vision is that it is absurd to conceive of the Brazilian homeland without the Catholic faith (Oliveira 1990).

It is interesting to cite the explanations accompanying the law proposed by the representative of Pernambuco Luiz Cedro: “... I have just sent the board a bill that would place under the protection of the State all buildings that are in the national interest from the point of view of history or art. (...) Old churches ... old colonial houses ... They represent to us the living tradition, the accumulated work of our predecessors ... and they constitute, for these reasons, a mirror that we must preserve to transmit it to Brazil's future generations" (apud Medeiros 2005: 5). In the report of the commission of Minas Gerais, the Church is recognized as one of the most interested parties in the preservation of historical heritage, and should be considered, thus, as an ally of the official policy (Iphan 1980). It is worth mentioning a 1938 text that requested that IPHAN designate the church 'Igreja de Nossa Senhora das Dores', located in Porto Alegre, as a landmark . ${ }^{10}$ It is limited to an account of the history of the church, , whose foundation dates back to the early $19^{\text {th }}$

10 File oog6-T-38, Archive of IPHAN. 
century, based on several documentary sources. The need to preserve religious architecture as testimony of a national past was one basic premise of those who worked with IPHAN, even if they did not have any direct relation with the Catholic Church.

Chuva (2006) summarizes the highlighted role of Catholic churches in the origins of IPHAN initiatives in this way: "the religious aspect of the colonial period was given excess importance- attributing an artistic value to the manifestations of power of the Catholic Church and to the material representation of Christian faith (...). The State also promoted the monumentalization of faith, from its own material structure" (217-8). This encouragement of monumentalization may be understood literally, to the extent that the churches, formally sites of worship, were transformed into national monuments. Unlike other countries, particularly in Europe, where a significant portion of religious buildings are no longer used as sites of devotion, in Brazil such a transfer of ownership and function is much more an exception than a rule. That is, many buildings were monumentalized while still functioning as places of worship.

The idea of giving excessive importance to the religious aspect also deserves comment. After all, it was not exactly because of their "religious" importance that churches and other Catholic objects were granted landmark status. This is possible, as we have seen, because they were seen to have historical and or architectural values. It was a vision that privileged the Baroque and the resistance of these buildings to the assaults of time that led to the protection of the churches and assimilated them into the formation of the nation. In a period in which criteria involving material culture prevailed, little is said about Catholicism and the Catholics who built and maintained these buildings. In fact, these Catholics sometimes become a hindrance to state policies. On the other hand, those same architectural and historical criteria gave rise to assumptions that exclude other possibilities, considering the Brazilian religious field, from becoming beneficiaries of protection and intervention policies. It is in this sense that the republican state recognized Catholicism as the national religion.

These conceptions, forged in the first half the $20^{\text {th }}$ century, are still found in the present. This can be verified by examining one of the articles in the Agreement between Brazil and the Holy See related to the legal statute of the Catholic Church in the country. This document was negotiated between 
Vatican authorities and the Brazilian government, and approved by the national Congress in 2010. ${ }^{11}$ Article 6 determines:

The High Parties recognize that the historical, artistic and cultural heritage of the Catholic Church, as well as the documents kept in its archives and libraries, constitute a significant part of Brazilian cultural heritage, and shall continue cooperating in the protection, appreciation and promotion of the enjoyment of the properties, movable and immovable, owned by the Catholic Church or by other ecclesiastical entities, that are considered by Brazil as part of its cultural and artistic heritage (apud Giumbelli 2011: 140)

We observe the expression "Brazilian cultural heritage", which confirms the association between Catholicism and nation. The document also indicates the form of administration of this heritage: it is still owned by the Catholic Church, while the state has certain rights of access to places and documents. Finally, we can also note an ambiguity in the formulation "owned by the Catholic Church or by other ecclesiastical juristic persons". Is the document recognizing the possibility that other religions be covered by the cultural and artistic heritage protection policies? Considering this possibility, we now return to the Afro-Brazilian religious universe.

\section{Candomblé Terreiros}

The landmark designation of the Casa Branca terreiro, concluded in 1984, by the decision made in the meeting mentioned at the beginning of this article, was a pioneer act. After an interregnum of approximately 15 years, other terreiros were designated as landmarks. A survey carried out in the IPHAN archives in September 2012, identified 21 processes. Most of them refer to houses located in Bahia. The remaining seven cases are distributed as follows: two in Pernambuco, two in Rio de Janeiro, one in Goiás, one in Sergipe and one in Maranhão. Except for the process of Casa Branca, the remaining took place between 1998 and 2009. We can conclude that there has been a proliferation of landmark designations of terreiros since the last years of the last century, in a wave that began in Bahia and reached other Brazilian states. ${ }^{12}$

11 For more details about this document, see Giumbelli (2011)

12 Some actions and projects with impact on Bahia created the conditions to enable the landmark designations (see Serra 2005). In the recent scenario, IPHAN has been promoting open debates about how to treat Afro-Brazilian 
Despite gathering basic information about the 21 cases, I only had access to the complete contents of seven of these designation processes. ${ }^{13}$ Considered as a whole, they took place between the years 1998 and 2004; except for one case, which occurred between 2008 and 2010. Five out of the seven terreiros are located in Salvador; one in Cachoeira, a municipality in Bahia's Recôncavo region; and the last one was in São Luis do Maranhão. The sample therefore reflects the predominance of the temples of Bahia. Below, I present an analysis of the seven processes I had access to. My intention is not to analyze the entire universe of the terreiros that were designated as landmarks, which would require access to the complete documentation for all of the cases. I will not analyze the seven cases in depth. My objective is to identify the points that support the proposals for landmark designation of terreiros. To this end, the presentation has two stages, first emphasizing the case of Casa Branca and then considering the remaining cases as a whole.

Casa Branca's designation process is distinguished from the others by more than its temporal situation. It was a difficult decision. Whereas in all the other six cases the designation was approved by unanimity or by a large majority of votes, the vote over Casa Branca was tight. At least two commentators (Serra 2005; Velho 2006) point out some resistance among the council members, a resistance that represented conservative visions about the notion of heritage and showed some discomfort in extending landmark designation to Afro-Brazilian religions. This type of resistance was clearly present. But I would like to call attention to some common points raised by those discussing the designation measure. In other words, while doubts and dilemmas were raised, they were not considered to be sufficient to reject the designation of Casa Branca.

The justifications for the landmark designation of the Casa Branca terreiro can be found in several parts of the process. ${ }^{14}$ I will emphasize the written contribution made by an anthropologist, which served as a legal opinion in favor of the designation, even though it is not technically so. In this text, Casa Branca is presented as one of the first terreiros of Ketu-Nagô origin in

religions. I could follow part of the III Forum of Candomblé Terreiros of Rio de Janeiro, held on 21 September 2012. See IPHAN (2012).

13 Files 1067-T-82, 1432-T-98, 1464-T-oo, 1471-T-oo, 1486-T-o1, 1481-T-o1, 1627-T-11, Archive of IPHAN. I thank the officers of the Archive of IPHAN for attending to my inquiries.

14 File 1067-T-82, Archive of IPHAN. See also França (2012). 
Brazil, from which many others arose. It has a double cultural significance: as the original impulse of a religious-cultural complex and as a symbol of the continuity of this complex. For this reason, it is important to recognize what this complex represents about the role Africans and their descendants played in the formation of Brazilian culture. Once its cultural significance was established, the protection of the terreiro was justified by an official measure. In the letter requesting the designation of Casa Branca, the president of the association that represents the terreiro asked why monuments of the black population would not deserve the same respect as that given to monuments of people of other origins.

It is interesting to observe that the responses to these arguments - which certainly existed - are not recorded in the documentation of the designation process. The objections raised by one or another board member at the meeting where the landmark designation of Casa Branca was approved touched on different points. One of them is the question of the ownership of the site where the Candomblé temple was located. The owner of the lands where the terreiro was located had already sold (or rented) part of them, and a gas station had been installed close to the entrance of Casa Branca. There was news that the terreiro would be evicted. The letter from the president of the religious association, one of the elements that serves as a basis for the request of the landmark designation of the terreiro, does not mention this measure; it prefers to request the expropriation of the site and the assignment of its permanent use. At the time of the IPHAN board meeting, the issue of ownership had not been resolved. Those in favor of the designation supported, expressly or implicitly, that the measure would be the most suitable way of solving the ownership question - and not the opposite. The de-facto solution came some months after the meeting that granted landmark status to the Casa Branca. This points to a common situation in the Afro-Brazilian religious universe: requesting landmark designation to confront threats or insecurity regarding the ownership of terreiros.

Another point raised at the same meeting was the adequacy of the designation measure to recognize the importance of a Candomble terreiro. Since landmark designation affects material objects and implies the preservation of their forms, it would spark the question: Is it possible to designate sites whose material elements are constantly transformed? If, for some, this questioning is linked to an affirmation that the constructions constituting a 
Candomblé terreiro lack architectural value, other questions would come into play. An architect from IPHAN, while admitting the need to add new types of cultural manifestations to the national heritage, suggested the creation of specific legislation for terreiros or similar sites. Two of the anthropologists that were more directly involved in the process also expressed their doubts. One of them considered other instruments more suitable than landmark designation and affirmed that the latter could only be applied if accompanied by a flexible interpretation of the legislation in force, so that the preservation measures do not become an obstacle for changes (in the spatial organization and the material domain) inherent to religious manifestations. The other even questioned the pertinence of the landmark designation, which would create a risk of immobilizing something that is essentially dynamic. Eventually, both gave their decided and decisive support to the petition for landmark designation, arguing that the measure should not prevent modifications to the architectural heritage and should not interfere in the internal organization of the community. In this way, the support given to the designation did not imply an absense of doubts about its adequacy, but a commitment to a kind of combination between preservation and transformation, between state recognition and religious autonomy.

Finally, another aspect allows joining two arguments presented at the IPHAN board meeting in objection to the designation of Casa Branca as landmark. Consulting the meeting minutes, we find that one of the council members affirmed that "the proposal for landmark designation was made with the assumption that this would guarantee the continuity of worship"; another, that, "since Candomblé is a ceremony, a religion, the temple is not a fundamental part of the doctrine". Both arguments seem to have Catholicism as unstated contraposition. To the extent that they point to a different application of heritage status, they identify a common field of perceptions from which a divergence is established between the exclusivity or non-exclusivity of the parameter constructed by reference to Catholicism. In the case of Catholic churches, the guaranty of continuity of the mass and other services or the intrinsic link between church and doctrine were not in question. As previously mentioned, a conception was formed that allowed the dissociation between religion and architectural or historical value. What we see in the case of the designation of Afro-Brazilian temples is the impossibility of establishing that distinction. If, it is possible to consider Catholic churches 
without the activities performed inside them, the processes related to Candomblé terreiros reject this separation. It is the link between the site and a specific group that forms the motive for a landmark designation. As the report of the rapporteur of the process affirms: "The landmark designation must be a guarantee of the continuity of the cultural expression that has in Casa Branca a holy space", with Candomblé understood as a religious system that is fundamental to the constitution of the identity of significant portions of Brazilian society.

From this set of considerations, we are now able to examine the remaining designations. As mentioned, we are not going to analyze specific cases but consider the six processes as a whole. It is worth repeating that in all these processes the approval of the designations was unanimous or attained a large majority of votes, indicating a change of sensibilities when compared to the situation surrounding the previous case. This unanimity in the decision may find some correspondence with the involvement of public personalities in the indication of the designation and the occurrence of previous recognitions. The process for the Gantois terreiro indicate designation was suggested by by the Minister of Culture; in another terreiro, the request came from the Mayor of Salvador; another, from a former employee of IPHAN. The municipal authorities of Salvador had already established protection measures for almost all the four terreiros of the municipality. The São Luis terreiro was the object of a proposal for landmark designation submitted by the Maranhão state agency responsible for heritage protection. Moreover, recognitions of a federal nature already benefited most of the terreiros located in Salvador. So here we have a series of signs that support the creation of a favorable atmosphere for the appreciation of terreiros.

I will divide my analytical remarks into three blocks. Each of them exhibit continuities in relation to the process with the Casa Branca process.

Form the point of view of the reasons and grounds for a designation, the issue of antiquity still plays a crucial role. This was true in all the cases. The Gantois and Axé Opô Afonjá terreiros are linked to Casa Branca by a common history that dates to the $19^{\text {th }}$ century. With a development parallel to them, Alaketo reiterates its condition as "one of the oldest of all known terreiros in Bahia". Casa das Minas is considered "the oldest Afro-Brazilian religious house of Maranhão". Zogbodo Male Bogun Seja Unde, located in Cachoeira, affirms it is the first Candomble terreiro founded by Africans of Jeje origin. In fact, there 
is a clear predominance, among the seven designation processes, of terreiros with a Jeje-Nagô reference. The exception is the Bate Folha terreiro, which is identified as "Angolan". The aspect of antiquity is also considered in the case of the later, as well as the prestige among other exponents of other "nations". In all the processes, the requests, reports, and reviews point to the historical connections with Africa, always referring to the epic of the slave trade and slavery in the colonial and imperial periods. The connections are either drawn in a generic way, or tracked in the course of specific individuals transported between America and Africa. The antiquity criterion, no longer related to an exclusive or specific lineage or "nation", seems to open a way for other cases in which landmark designation of terreiros is requested. Notice that all the terreiros in question were registered in IPHAN's Historical Record Book.

On the other hand, it is interesting to note that none of the terreiros were registered in the Fine Arts Book, but they were also registered in the Archaeological, Ethnographic and Landscape Book. This gives rise to an important discussion related to other grounds raised to support the protection measure. Because the material dimension expressed in architectural terms is crucial in the determination of landmark designation or tombamento, the way these dimensions are considered is questioned in the case of Candomble terreiros. The report of an architect included in the designation process for the Alaketo terreiro of Salvador offers a good observation. It is not possible, the report affirms, to appreciate the architecture of a terreiro without considering "mythical and ethnic values", in which not the reproduction but the representation of Africa comes into play. The report mentions as a distinctive feature of the buildings found in the terreiros their simplicity and the direct relationship established between the spaces and their functions. In the eyes of European culture, it would not be a temple; but Afro-Brazilian values produce another perspective. The architect concluded: "This cultural symbiosis results in the vernacular civil architecture present in Alaketo, both typical and unique, in its urban externality as well as in its cultural role." The adoption of other parameters, therefore, would allow the production of the appropriate references to appreciate the material elements present in terreiros.

Nevertheless, the lack of registration in the Fine Arts Book - where many Catholic churches are registered - points to a tension in the reasoning used in the appreciation of the architecture of the terreiros. The intrinsic 
relationship between spaces and functions thus reveals the path that leads from esthetics to use, privileging the latter. A report in the process for the designation of the Casa das Minas provides another example of this reasoning, by confirming the close connection between the physical structure and the worship activities - as shown by the preservation of dirt floors. Its simple constructions house a "holy temple", which can be disguised by a type of "social mimicry", necessary in a society with prejudice. The process of the Zogbodó terreiro affirms something similar: the simplicity of the architecture and the materials is based on religious orientations, its construction takes place through rituals. The relation between spaces and uses, which were analyzed to help understand the internal configurations of terreiros, can be extended to encompass aspects of another order. I refer to the links established between, on the one hand, the long-term existence of Afro-Brazilian terreiros and, on the other, the consolidation of subaltern models of residence and the urbanization of peripheral regions. On another plane, the same may be verified when the contribution of terreiros to the preservation of green spaces in big cities is affirmed. The Bate Folha terreiro, in Salvador, is praised as a "center of ecology and culture".

The emphasis on use or function for the suitable appreciation of the material elements that constitute the terreiros reiterates the idea that the recognition of these places is strongly connected with the communities that bring them to life. It is significant that in two of the processes analyzed, the possibility of protecting terreiros as examples of "immaterial heritage" is raised..$^{15}$ In the process concerning the Gantois terreiro a council member proposes that terreiros should be registered as protected places, since they represent a "spiritual value". This value is materialized in the richness of Catholic constructions yet is more difficult to perceive in the case of terreiros due to their material modesty. The report in the case of the Bate Folha terreiro confirms that it is a designation process inserted "in a still restricted and very peculiar series of monuments". In them, there is a bridge between material and immaterial references; in the latter dimension, a cultural aura is established in the sense that it broadens previous uses, enabling the recognition of a "subaltern authenticity". Spiritual value and subaltern authenticity can be

15 This is another modality of official protection, in force since 200o, which does not consist in a landmark designation, but in the registration of objects and the ways they are made. See IPHAN's website: http:/|portal. iphan.gov.br/portal/montarPaginaSecao.do?id=10852\&retorno=paginaIphan (Access on 07/10/2014) 
seen as operators of this passage that goes from the material dimensions to the social organization of a group that supports a temple. It is significant that one of the participants in the meeting of IPHAN's advisory board in which the registration of terreiros as immaterial heritage was proposed raised a warning: it would be necessary to consider the secrecy that preserves some aspects of the worship and which would be put at risk with the state registration.

One specific opinion report prepared in the process involving designation of the Axé Apô Afonjá terreiro is worth analyzing to see how some of the issues mentioned are articulated. The person who prepared the report also issued an opinion in three other processes, thus becoming a key actor in these cases. The situation of this terreiro is interesting due to the fact that it does not suffer from problems of a material order or related to land. After an introduction, in which it was affirmed that the doubts about the adequacy of designating terreiros as landmarks no longer existed, the report addresses the "reorganization of African rituals in Brazil", pointing to the Jeje-Nagô cultural hegemony established in the $19^{\text {th }}$ century in Bahia as being strongly influential in the general structure of Candomble terreiros. The following item concerned the "space model of Jeje-Nagô terreiro", which was described on the basis of an anthropological bibliography. Finally, the report specifically addresses the terreiro in question, presenting its history and assessing its correspondence with the model described in the previous item. It notes that the small forest at the terreiro is a landscape reference in the part of the city where it is located. The terreiro should still be seen as a driver of to urbanization, testimony of the non-exclusivity of European architectural and urbanistic models. One passage from the opinion clearly illustrates and summarizes some points discussed:

"The relationship of the cult community with the space of the terreiro is of an extremely holy nature. Orixás can only be worshipped there, (...) because the axé (spiritual force) of the house is planted at its symbolic center and without it, nothing exists or can exist. This is why the preservation of the space is essentially important for the continuity of the religious manifestation. In this way, the space of and the architectural transformations suffered by a terreiro are always inherent to the dynamics of the ritual or the desire for its exaltation. In the case of Axé Opô Afonjá, the concern for its preservation has always been present, as demonstrated by the conservation of the terreiro area, the buildings and the initiatives carried out for the social development of the community. Without people and without a terreiro, there is no Candomblé". 
We can note how transformation and preservation combine, in this narrative, as part of the existence of the terreiro. In another line of thinking, the place and its materiality are presented as the base where the rituals occur; but this is only possible because it is simultaneously affirmed that the ritual activities guide and support the material references. It could be said that without Candomblé, there is no terreiro. Another interesting aspect in this report is how two seemingly opposite ideas are interlaced. The report affirms that a terreiro recreates African religious geography and, at the same time, reflects the conditions of creation of a Brazilian religion. It also states that as the result of the cultural resistance of black slaves, the terreiro is a Brazilian invention. This means that the terreiro is at the same time African and Brazilian. This formulation reiterates points that had already appeared in the Casa Branca designation process. However, if we recognize that this is something that has been ratified and disseminated in the most recent cases, we observe a reinforcement of the connection between Afro-Brazilian religion and national culture. The Afro-Brazilian religion is not only the testimony or legacy of a portion of the population - an "affirmation of the Afro-Brazilian ethnic identity" and a "document of the history and cultural resistance of black people" - but it is also a vector composing the entire national culture, one that is now seen as necessarily plural and multifaceted. ${ }^{16}$

In another text (Giumbelli 2008), I sought to demonstrate that the recognition of Afro-Brazilian religions often depended on an argument that emphasized the specificity of these religions. This specificity, in turn, is based on the use of the notion of culture in the ethnic sense, associating Candomble and other religious variations with expressions of Africanness. However, the arguments supporting requests for landmark designation, while reiterating these associations, seek to emphasize another vector, which forces us to reconsider the conception of Brazilian culture itself. In other words: it is not only a question of defending the specificity of these religions, but about emphasizing how they affect the way that the entirety of

16 The same articulation of vectors can be seen in another report, related to the Gantois terreiro: "It serves as a unique reference in the chronicle of a population that had a distinctive importance in the formation of the richness of Brazil, in the construction of its identity and culture. It is an expressive monument of the city of Salvador, a reason of pride for Bahia and for Brazil; it evokes the heroic deeds of Africans and Afro-descendants in this country, the memory of great black priests and priestesses who gained the respect of all and won the love of their population; it evokes a history that Brazilians of all origins appreciate, a legacy of great civilizations, a testimony of our precious African inheritance". 
the Brazilian nation itself is conceived. Similarly, the notion of culture used, apart from reiterating an ethnicized reading, is based on a more general understanding. There is thus a transformation of the concepts of culture and nation used to defend the designations between the cases of the Catholic churches and the terreiros..., a point to which I will return in the conclusions.

These reconfigurations are reflected in manifestations that establish a specific proximity between state and religion. Many occurrences of this can be found in the landmark designation processes. In the meeting of the IPHAN Advisory Board related to the designation of the Axé Apô Afonjá terreiro, one director of IPHAN spoke about Xangô. Another reference was made to Xangô in the meeting when the case of Gantois was discussed. In the meeting that approved the designation of Alaketo, the main leaders of the terreiro were present and were greeted by the Minister of Culture himself, whose argument praised a synergy between Greece and Africa. The report on the designation process for Casa das Minas mentions that, according to the leaders of the terreiro, the voduns (entities similar to orixas) had given their agreement to the designation proposal. Finally, in the meeting related to the Bate Folha terreiro, an official from the Ministry of Culture affirmed that in the mid 1980 os he was protected by an amulet he received at Casa Branca. He was the person who presided over the meeting that evaluated the designation of Casa Branca. After the tense meeting, he and other council members went to the terreiro, joining the devotees that were there waiting. Would these expressions correspond to the recognition of "ecclesiastic power" in normatives of the state body and to the presence of ecclesiastical authorities in meetings? They are at least the product of a reconfiguration that enables the recognition of terreiros as cultural heritage.

\section{Christ the Redeemer Monument ${ }^{17}$}

In this section, I examine IPHAN's landmark designation process for the Christ the Redeemer monument, which took place between May 2001 and August 2006. It is an element, among others, in the recent representations

17 This material was first presented at an event of the Laboratory of Symbolic Analysis, Graduate Program in Sociology and Anthropology (Programa de Pós-Graduação em Sociologia e Antropologia), Federal University at Rio de Janeiro, 03.24.2009. The citations were extracted from File n. 1478-T-o1, from the IPHAN archives, with the assistance of Izabella Bosisio. 
and interventions about this monument that was conceived in the 1920 and inaugurated in 1931. With no intention of being exhaustive, it is possible to mention: the 75th anniversary celebration in 2006 and the 8oth in 2011; its election to be included among "the new wonders of the world" in 2007; and its transformation into a sanctuary by the Archdiocese of the City of Rio de Janeiro in $2006 .{ }^{18}$ My analysis considers some of the components of the process, from the document of 2000 that originated the designation process to the decision by the IPHAN advisory board in 2005. The objective is to show how religion and nation are articulated in the elements of the process, which can only be done when we consider how this articulation was produced at the moment the statute was conceived and constructed.

There is a question that runs through the whole designation process, appearing several times: in the initial memorandum, in the legal reports, and in the expression of surprise of a council member at the meeting where the decision was made: How is it possible that the monument had not been designated earlier? An essential answer to the question is found in the technical report issued in 2002 by an architect from IPHAN. "It is interesting to note how the report presents the importance of the monument and its designation as self-evident. The report states that it seeks to demonstrate "the reasons why it became the most important symbol of this city", and, more widely, a "national symbol". The references to the statue include postcards, airline advertisements, songs, souvenirs, popular opinions and newspaper columns. In this way, the most specific arguments - to which I will return below - are contained in the idea of "recognition" of the "value" of this monument. Similar terms are present in other statements: which identify the monument as a "mark of Rio de Janeiro and a national symbol"; with "symbolic relevance" (which settles a debt with the history and memory of the city of Rio); as having "symbolic importance and magnificence"; and which has "cultural importance at a national level".

A report issued by one council member takes the same direction, invoking "the popular imaginary of the Christ, as well as the personal impressions and remembrances of each person" in regard to the monument, which the report refers to as a "symbol of redemption and freedom". Its value, it

18 Analyses about the past and present of the Christ the Redeemer statute appear in an abridged way in this text; for details and sources, see Giumbelli (2014). 
continues, is "special and flagrant": "I want to propose the recognition of an Emblematic Value for the Christ statue of the Corcovado. A value that I see as historical and universal. A value that adheres to, to cite few and strong examples [an approach that was already suggested in the technical report], the Pyramids of Egypt, The Eiffel Tower in Paris, the Statue of Liberty in New York (...), the columns of Niemeyer's Palácio da Alvorada in Brasilia”.

I will continue to highlight the convergences and divergences of the technical report in relation to the opinion report of the council member. The technical report proposes the registration of the monument in three of the four IPHAN books: the Historical Book, the Landscape, Ethnographic and Archaeological Book, and the Fine Arts Book. It is an engineering milestone of its time, the largest monument in reinforced concrete constructed until that date. The report affirmed that the statue is the "most important symbol of this city and of the country", and is perfectly integrated to the landscape. It is, finally, a successful example of Art Deco; or, more simply, there is an appeal to its evident and "explicit" beauty, the "unquestionable harmony of its lines".

But the registration as an artistic monument generated controversy: Is Art Deco a style worthy of tribute? Does the Deco statue have any significance for the memory of art in Brazil? The report of the council member proposed that the statute should be attributed "an emblematic value" adding: "the power of symbolization is not always proportional to the artistic beauty. And it does not necessarily derive from the landscape interest”. It thus suggested that the Christ the Redeemer should only be registered in IPHAN's Historical Book, which was what finally occurred.

According to the report of the council member, the historical value interacts mainly with the present that validates the monument symbolism as an emblem of the city or country. However, the technical report there is a line that emphasizes a strictly historical analysis, focusing on the technology and esthetics of reinforced concrete, and especially on the reconstruction of a "context" that dates back to the period between the wars. I would like to examine the report's position concerning two vectors that permeate the image of the monument: religious discourses and uses, and non-religious discourses and uses.

When referring to the context, the report emphasizes two topics: modernity and nation. After World War I, the world was in a crisis characterzed 
by a break with the past, innovation, it was a time when being modern was imperative. In Brazil, this situation was accompanied by a debate about the national identity, which mobilized an ideological dispute. The Christ the Redeemer monument, in that context, is the symbol and conquest of a crusade launched by the Catholic Church and its militants for the restoration and Christianization of society. The report of the council member, however, attributes the realization of the monument to a specific ideological current, while confirming the importance of a broader dimension. Mentioning the success of the campaigns to raise funds - which made "each Brazilian a contributor in the sense of making its construction feasible" - the report concludes: "the Christ the Redeemer monument was born, as it was intended to be, as a national monument".

However, it is possible to affirm that, for those who conceived the monument, the nation was less a support than the target public of the Christ statue. The Christ, as a strictly Catholic reference, should rule over Brazil, showing Brazilians the most adequate path to redemption. In the reading of the report, the nation, independent of religious marks, is always the subject of the process. The monument is presented as an expression of the "conjunction of political and ideological forces that composed Brazilian society at the end of the Old Republic (República Velha, 1889-1930)". In this sense, the future would simply illuminate the original moment: "This image (of the national monument) will be consolidated over the years and will end up becoming the spoken portrait of the country".

This understanding leaves the opinion report with a paradoxical quality: on one hand, it recognizes a religious dimension in the monument; on the other hand, it contributes to the process that bypasses this dimension. The report states for example: "It never became a pilgrimage site and few people visit it for its Catholic symbolism. The monument has gradually become unsacred and was incorporated to the image of Rio de Janeiro, thus becoming the trademark of the city." "Independent of the religious connotation...", it is seen as "a friend of the city". The observations contained in the report regarding the Corcovado before the existence of the Christ there can be seen in the same sense: the touristic importance of the site existed since the $19^{\text {th }}$ century (as the most visited belvedere of the country and one of the most photographed landscapes). The landmark designation is thus based on the operations that turned the statue into part of the landscape, natural and human, that surrounds it. 
In sum, if it is history that is seen as the foundation for recognizing the heritage value of the Christ the Redeemer monument, the protagonists in the process are, more than religion, the city and the nation. Unlike the supporting arguments that saw the persistence of the past in the present, emphasizing the importance of Catholicism, here it is the present that projects to the past. City and nation, containing the marks of present conceptions, are taken to the moment the monument was conceived and constructed. This way of referring to and appreciating the monument interacts with the preponderant ways of relating with the Christ the Redeemer, characterized by the accumulation of meanings, far beyond a specifically religious one. In this way, the monument acquires the nature of a tourist site, in detriment to its artistic or architectural dimension. Therefore, the place is connected not with a specific group, but with an essentially varied set of uses and appropriations. This variety also colors the way of conceiving city and nation.

\section{Conclusions}

The three sections of this text present different articulations between state initiatives for heritage protection state and religious universes. In reference to Catholicism, the cases considered here cannot be considered a synthesis of those in which the relationship between landmark designation policies and religion is present. It would at least be necessary to consider situations in which Catholic temples are part of larger architectural complexes, as in the case of "historical cities". In these cases, what is the importance and meaning of the "religious" aspect in the appreciation of the "architecture" and the "history"? Even if we recognize this limitation, the material analyzed here allows comprehending the outlines and dislocations that mark the impact of heritage protection policies on religion. With respect to Candoblé terreiros, I think that the elements of the documents to which I had access offer a sufficient vision about the questions surrounding the opening of heritage protection policies in the universe of Afro-Brazilian religions. If this is correct, we find solid grounds to accompany the consequences of this opening, whose existence is indicated by the significant amount of ongoing designation processes.

Two points guide my final considerations. The first concerns what I call regulation of the religious (Giumbelli 2013). It may be considered that the 
heritage protection policies reconfigure the outlines, statutes and meanings of the religious by having an impact on so-called or so-claimed "religious institutions". In the case of Catholicism, it seems to me that this effect is produced in at least two senses. The recognition of churches for their architectural or historical value supports the argument of the social or cultural importance of Catholicism. In this sense, it can provide elements that contribute to having Catholicism justify its presence in non-religious spheres through its leaders, spokespersons and advocates. On the other hand, the same cultural appreciation can work in the inverse sense, as the report of the council member in the process of the Christ the Redeemer clearly shows, by reiterating the statement of the technical report: "With the designation, IPHAN participates in the public management of a private property - originally characterized by a religious vision, and which then gradually acquired a cultural sense". In this case, the cultural recognition seems to occur in detriment to the religious. It is worth recalling that landmark designation always attributes authority to another agent in the administration of a temple or sanctuary.

In relation to the Afro-Brazilian religious universe, I would like to call attention to other processes that can be understood with the help of the concept of regulation. A first point has to do with the demand for designation measures itself or to the appeal to the state agencies responsible for cultural policies. Even though this demand or appeal always involves agents and mediators of various natures, we can note that the religious agents themselves tend to make these appeals. The requests for landmark designation are thus within the horizon of possibilities of a significant number of terreiros. In one of the cases analyzed, that of the Zogbodo Male Bogun Seja Unde terreiro, in Cachoeira, Bahia, there are divergences within the religious group about requesting the landmark designation request, but the decided to do so. Moreover, the bylaws of the association representing the terreiro, drafted in 2003, include the idea of "heritage preservation". The existence and foundation of "museums" connected with terreiros ${ }^{19}$ can also be associated with this incorporation by the Afro-religious universe of a cultural dimension, not only in an ethnic sense, but also in line with the interpretations that

19 For a case in Recife, see Campos et al (2012). There are also cases in the inverse direction, related to the creation of museums with Afro-Brazilian elements that wind up encompassing religious objects and dimensions (Sansone 2012). 
guide the vision and actions of state bodies involved with the "promotion of culture" in a universalist sense.

The second point of my final considerations seeks to summarize two movements. The arguments supporting the proposals for landmark designation of terreiros question a certain narrative that focuses on an issue of nationality. While making us reconsider the notions of heritage, architecture, history, and culture, these arguments indicate the Eurocentrism that presides over the hegemonic narrative of nationality. ${ }^{20}$ Instead of the common story by which Europeans facilitated their encounter with Africans and Amerindians, what is suggested is a story told from the point of view of those who came from Africa and in which alternative references were produced in terms of religiosity and architecture. In this conception, the nation gains new points of view, helping in the perception of its diversity. Catholicism no longer corresponds to the entire social and cultural formation that is a synonym of nation, and it becomes a part at whose side other parts may be placed. It is the conception of Brazilian culture itself that is open for reconsideration.

The other movement I think it is possible to identify in the material analyzed here concerns a certain interplay between nation and religion. The process related to the designation of the Christ the Redeemer monument shows an encompassing of the religious by the national. This encompassing is different from that operated in the past, regarding Catholic temples and references, to the extent that it is opened to other recognitions, as shown by the cases involving Afro-Brazilian terreiros. For this reason, the most interesting question seems to be not the one related to the possible stabilization effects of what is designated, but how the processes of redefinition of what is national and what is religious are developed in a mutual and involving way. The application of the "immaterial heritage" instrument seems to give even more dynamism to these processes. In terms of Afro-Brazilian religions, the process involves the recognition of these religions - and not of specific temples. In terms of Catholicism, it favors the recognition of feasts, discourses and places linked to folk practices (as opposed to the ecclesiastical). ${ }^{21}$ The conjunction

20 I consider this effect more important than the risks pointed out by Johnson (2005) of "loss of cultural autonomy" of Afro-Brazilian religions due to their state recognition.

21 Regarding Umbanda and Candomblé as immaterial heritage, this occurred in 2009 in Rio de Janeiro, cf. news: http://www.alerj.rj.gov.br/common/noticia_corpo.asp?num=30901 (Access on 07/10/2014). In the case of Catholicism, several celebrations have already been registered in IPHAN as immaterial heritage, cf. list: http:/l portal.iphan.gov.br/portal/montarPaginaSecao.do;jsessionid=C281DEF854B2B 72D22D 76454CoB127DF?id=12456\& 
of these measures aimed at defending heritage, in whose name conceptions about the nation are developed, establishes a panorama with many situations that certainly deserve to be accompanied by our research.

Received December 30, 2013; approved June 01, 2014.

Translated from the Portuguese by Lingua 2, revised by Jeffrey Hoff

\section{References}

BIRMAN, Patrícia. 1997. “O campo da nostalgia e a recusa da saudade: temas e dilemas dos estudos afro-brasileiros”. Religião e Sociedade, 18 (2): 75-92.

BRANDÃO, Carlos Rodrigues. 1988. "Ser católico: dimensões brasileiras - um estudo sobre a atribuição através da religião”. In: V. Sachs (org.). Brasil e EUA: religião e identidade nacional. Rio de Janeiro: Graal.

CAMPOS, R. B. C. ; LIMA, Carmem L.S. ; LIMA, G. J. ; SILVA, Eliane

Anselmo. 2012. "Os Desafios de Xambá, um terreiro que virou quilombo: sincretismo e africanidade em análise”. In: Sylvana Brandão (Org.). História das religiões, v. VII. Recife: Editora Universitária-UFPE, p. 123-145. CAMURÇA, Marcelo; GIOVANNINI JR, Osvaldo. 2003. "Religião, patrimônio histórico e turismo na Semana Santa em Tiradentes (MG)”. Horizontes Antropológicos, 19: 225-247.

CHOAY, Françoise. 2001. A alegoria do patrimônio. São Paulo: Unesp.

CHUVA, Márcia Regina. 2009. Os Arquitetos da Memória. Rio de Janeiro: Editora da UFRJ.

COMAROFF, J. L. \& COMAROFF, J. 2009. Ethnicity, Inc. Chicago: University of Chicago Press.

CUNHA, Christina Vital da. 2008. “'Traficantes Evangélicos': novas formas de experimentação do sagrado em favelas cariocas”. Plural, 15:23-46.

FERNANDES, Rubem César. 1994. “Aparecida”. In: Romarias da Paixão. Rio de Janeiro: Rocco.

FRANÇA, Dilaine. 2012. Àròyé: um estudo histórico-antropológico do debate entre discursos católicos e do candomblé no Pós-Vaticano II. João Pessoa: Editora UFPB.

FRY, Peter. 2005. A persistência da raça: ensaios antropológicos sobre o Brasil e a

retorno=paginaIphan (Access on 07/10/2014). 
África Austral. Rio de Janeiro: Civilização Brasileira.

GIUMBELLI, Emerson. 2011. "O Acordo Brasil-Santa Sé e as relações entre Estado, sociedade e religião”. Ciencias Sociales y Religión, 14: 119-143.

GIUMBELLI, Emerson. 2013. "The problem of secularism and religious regulation: anthropological perspectives". Religion and Society - Advances in Research, 4.

GIUMBELLI, Emerson. 2014. Símbolos Religiosos em Controvérsias. São Paulo:

Terceiro Nome.

GOMES, Edlaine. 2010. "Dinâmica Religiosa e Trajetória das Políticas de Patrimonialização: reflexões sobre ações e reações das religiões afrobrasileiras". Interseções, 12: 131-158.

GONÇALVES, José Reginaldo. 1996. A Retórica da Perda: os discursos do Patrimônio Cultural no Brasil. Rio de Janeiro: UFRJ.

GONCALVES, José Reginaldo. 2007. Antropologia dos Objetos: coleções, museus e patrimônios. Rio de Janeiro: IPHAN.

HANDLER, Richard. 1988. Nationalism and the politic of culture in Quebec. Madison: University of Wisconsin Press.

IPHAN. 1980. Proteção e revitalização do patrimônio cultural no Brasil: uma trajetória. Brasília: MEC.

IPHAN. 2012. O Patrimônio Cultural dos Templos Afro-Brasileiros. Contagem: Oiti.

JOHNSON, Paul C. 2005. "Three Paths to Legitimacy: African Diaspora Religions and the State." Culture and Religion, 6 (1): 79-105.

MAIO, Marcos Chor e SANTOS, Ricardo Ventura (orgs.). 1996. Raça, Ciência e Sociedade. Rio de Janeiro: Fiocruz/ CCBB.

MEDEIROS, Ana Elisabete de Almeida. 2005. Pernambuco Falando para o Mundo. In: VI Seminário Docomomo Brasil, 2005, Niterói. Disponível em http:/|www.docomomo.org.br/seminario\%206\%20pdfs/Ana\%20 Elizabete\%20de\%20Almenida\%20Medeiros.pdf, acesso em 30.08.2013.

MONTERO, Paula. 2012. "Controvérsias religiosas e esfera pública: repensando as religiões como discurso". Religião \& Sociedade,32 (1): 167-183.

NOVAES, Regina. 2002. "Crenças religiosas e convicções políticas: fronteiras e passagens”. In: L. C. Fridman. (Org.). Política e Cultura no Século XXI. Rio de Janeiro: ALERJ/Relume-Dumará.

OLIVEIRA, Lucia Lippi. 199o. A Questão Nacional na Primeira República. São Paulo: Brasiliense. 
RIBEIRO, Emanuela Sousa. 2009. Modernidade no Brasil, Igreja Católica, Identidade Nacional - práticas e estratégias intelectuais: 1889-1930. Recife: Doutorado em História, Universidade Federal de Pernambuco.

SANCHIS, Pierre. 1994. “O repto pentecostal à 'cultura católico-brasileira”. In: Vários autores. Nem Anjos nem Demônios: interpretações sociológicas do pentecostalismo. Petrópolis: Vozes.

SANSONE, Livio (Org.). 2012. Memórias da África: patrimônios, museus e políticas das identidades. Salvador: EDUFBA.

SANSONE, Livio e PINHO, Osmundo (orgs). 2008. Raça: Novas Perspectivas Antropológicas. Salvador: Associação Brasileira de Antropologia/EDUFBA.

SCHWARCZ, L. K. M. 1999. “Questão racial e etnicidade”. In: Sérgio Miceli. (Org.). O que ler na ciência social brasileira (1970-1995) Antropologia. São Paulo: Sumaré, pp. 267-326.

SERRA, Ordep. 2005. "Monumentos negros: uma experiência”. Afro-Asia, 33: 169-205.

SILVA, Vagner Gonçalves da. 2006. "Sagrados e Profanos: religiosidades afro-brasileiras e seus desdobramentos na cultura nacional”. In: Emanoel Araujo (Org.). Catálogo do Museu Afro Brasil. São Paulo: IFF / SEPPIR, pp. 149-157.

VAN der VEER, Peter. 1994. Religious Nationalism. Hindus and Muslims in India. Berkeley: University of California Press.

VELHO, Gilberto. 2006. "Patrimônio, negociação e conflito". Mana, 12 (1): 237-248. 